\title{
Analysis of the electric energy consumption components for mine train traction
}

\author{
Serhii Arpul ${ }^{1}$, Viktor Artemchuk ${ }^{1}$, Mykola Babyak $^{2}$, Viacheslav Vasilyev ${ }^{1,}{ }^{*}$, Hennadii Hetman ${ }^{1}$, and Serhii Marikutsa ${ }^{1}$ \\ ${ }^{1}$ DNURT, Department of Electric Rolling Stock of Railways, Lazariana St. 2, Dnipro, 49010, Ukraine, \\ ${ }^{2}$ DNURT, Lviv branch, Department of Transport Technologies, I. Blazhkevich St. 12-a, Lviv, 79052,Ukraine
}

\begin{abstract}
The paper considers the issues of reducing the energy intensity of transportation at opencast mining enterprises, the relevance of which has now increased due to the rise in the cost of fuel and energy resources. It presents the study results concerning the cost structure of the electricity consumed by electric mine transport, which form the basis for the development of technical and operational measures to reduce the energy intensity of the transportation process. It is shown that the work to reduce the electricity consumption for mined rock transportation should be aimed at:

- Reduction of losses in the power circuits of the traction rolling stock due to the use of more advanced electric rolling stock and regulation of the degree of utilization of the installed traction power;

- Introduction of new contact materials for electrical circuits with the lowest possible resistivity, including for current collector plates;

- Introduction of measures to reduce energy consumption for power supply of auxiliary circuits;

- Development and implementation of rational train control techniques.

The introduction of energy-saving measures should include the development and application of effective methods for calculating individual norms of energy consumption and incentives for energy saving of the employees involved in the organization of the transportation process.
\end{abstract}

\section{Introduction}

Opencast mining enterprises are large consumers of electrical energy. Thus, for iron-ore mining plant, the total mine (i.e., taking into account all types of work) specific energy consumption in some cases reaches 50 $\mathrm{kWh}$ per 1 ton of mined ore. It is determined by the energy consumption of the entire complex of equipment that provides the technological process of production, and of all auxiliary workshops.

However, the analysis of the mine energy consumption structure shows that the most energyintensive process is the transportation of mined rock. When used in public works, electric traction can account for $85 \%$ of the total cost of electrical energy in a mine.

The development of an open-cast mining method is accompanied by increased concentration of production, growth in the depth and spatial dimensions of the mines, transportation distances and the complexity of delivery of mined rock to the surface.

With the increase in mine depth, the distance of transportation and the corresponding costs of electricity grow.

Raising the lift height by 1 ton of mined rock using rail for every $100 \mathrm{~m}$ increases energy consumption by approximately $2.5 \mathrm{kWh}$. The same indicator for the rest of the mine equipment in other technological processes (excavation, drilling, drainage, lighting, etc.) is only $1.03-1.05 \mathrm{~kW} \mathrm{~h}$.

It follows from the above that the development of mining enterprises that use electric traction in open-cast work will be accompanied by the increase in the transport component in transportation energy intensity. Therefore, the development of measures to save electricity in mines should include the implementation of reserves to save electricity costs for the transportation of rock with the aim of introducing energy-saving accounting technologies and reducing electricity consumption by rail, including using the advanced contact materials.

The purpose of the article is to analyse the reserves for reducing the energy intensity of rail transportation at mining enterprises that use electric traction during openpit mining.

\section{Literature review}

The electricity cost recovery for train traction make up a sizeable share of the operating costs of railways, so the entire history of their electrification is inseparably linked with the search and implementation of reserves to reduce the energy intensity of transportation.

The issues of energy saving have acquired particular relevance in the last decade due to rising energy prices. The number of works devoted to saving electricity for 
train traction has increased. In the field of the researchers' view there are both main links that determine the overall energy balance of electric traction power supply devices and traction rolling stock [1 - 6]. Some researches are aimed at improving the interaction of rolling stock with infrastructure, including through the organization of rolling stock repair systems and the introduction of resource-saving technologies and modern electrical circuit materials [7 - 15]. A number of new studies are devoted to the improvement of methods for rationing electricity consumption for train traction [16, $17,18]$.

The problem of saving train traction electricity in relation to main railway lines has been studied for almost the entire history of the railway electrification. As a result of the introduction of various energy-saving measures, the expansion of the electric traction range was accompanied by a significant reduction in the energy intensity of transportation. So, during the period 1950-1975, at the former USSR railways, the specific electric power consumption for train traction in all types of traffic decreased from 218 to $125 \mathrm{kWh} / 10^{4} \mathrm{t} / \mathrm{km}$ gross, i.e., by about $42 \%$ (see Fig. 1).

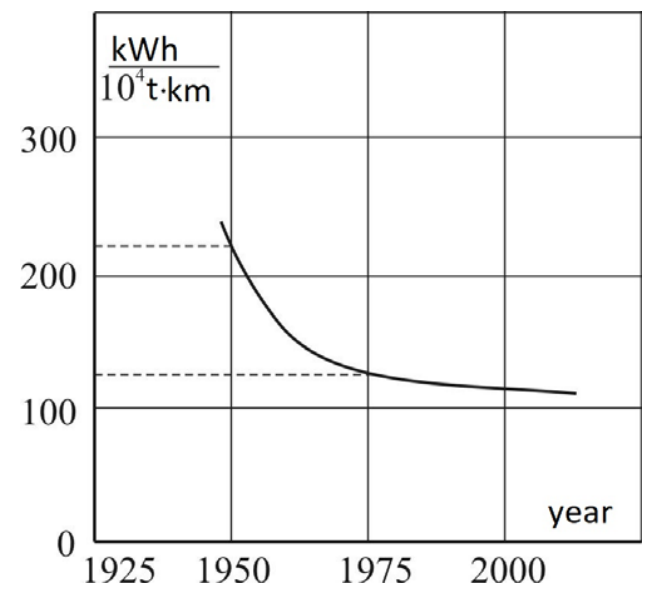

Fig.1. Specific energy consumption for train traction at the USSR railways

The energy intensity of mine electric transport is determined by a significant number of factors $[19,20$, 21] (characteristics of the traction power supply system and the operating rolling stock, track gradient and layout, travel routes, traffic volume, train driving modes used, train crew qualifications, condition of the track superstructure, seasonality, organization of work of the traffic control service, etc.). The development of energysaving measures and an effective method of rationing the energy consumption for traction in relation to the conditions of a particular enterprise should be based on the results of an impact analysis of these factors. First of all, it is advisable to present the total energy consumption in the form of components corresponding to the work of traction motors in overcoming the motion resistance forces differing in the nature of their origin. In addition, it is necessary to obtain a comparative assessment of the energy intensity of individual phases of the transportation process (loading, weighing, movement with cargo, etc.).
The main purpose of this analysis is to determine: - Importance of the components (share) in the total consumption of electricity for traction;

- Degree of influence of individual factors on the energy intensity of transportation.

As the analysis of literary sources shows, the issues of reducing the energy intensity of transportation by open-cast railway transport have not been studied fully to date. In particular, they lack studies of the structure of the component costs for the transportation of the mined rock and the factors that determine it, which are necessary for the definition and realization of energy saving reserves. This paper attempts to fill this gap.

\section{Subject matter}

From a practical point of view, it is of interest to analyze the components of electricity consumption for:

- Traction (overcoming the motion resistance forces, covering losses in the brakes and in the electric circuits of the locomotive, power supply of auxiliary circuits);

- Performance of individual operations of the transportation process (loading, unloading, movement with cargo, movement into the pit, weighing);

- Power supply of auxiliary circuits (fan and compressor engines, heating and air conditioning devices, etc.).

The energy balance equation for a journey can be represented as

$$
\mathrm{A}=\mathrm{A}_{\mathrm{T}}+\mathrm{A}_{\mathrm{AU}}
$$

and

$$
\mathrm{A}_{\mathrm{T}}=\mathrm{A}_{\mathrm{r}}+\mathrm{A}_{\mathrm{i}}+\mathrm{A}_{w_{M}} \pm \mathrm{A}_{\mathrm{P}}+\mathrm{A}_{\mathrm{BE}}+\mathrm{A}_{\mathrm{BR}}+\Delta \mathrm{A},
$$

where $A_{T}$ - electricity consumed for traction (work of traction engines and losses in power circuits); $\mathrm{A}_{\mathrm{AU}}-$ electric power consumption for auxiliary power supply; $\mathrm{A}_{\mathrm{r}}, \mathrm{A}_{\mathrm{i}}$, and $\mathrm{A}_{w_{M}}-$ work of the motion resistance forces, respectively, for the curves and track gradients and the main one; $A_{P}-$ work of forces to change the potential energy; $A_{B E}-$ energy consumption during independent braking on excessive gradients; $\mathrm{A}_{\mathrm{BR}}-$ energy loss in braking devices (excluding $\mathrm{A}_{\mathrm{BE}}$ ); $\Delta \mathrm{A}-$ energy losses in electric traction circuits of an electric locomotive in traction mode.

To determine the electric energy consumption for traction and auxiliary services supply, we used the electronic kilowatt-hour meters of the type SKVT-F604, designed for electricity metering on the electric rolling stock of railways and public transport. The remaining components of the energy consumption were determined by calculation according to the method described in [22].

Based on the analysis of experimental and calculated data, it was established that the share of $\mathrm{A}_{\mathrm{T}}$ in the total energy consumption is $88-92 \%$. When the elevation difference, where the loading and unloading points are located, is $100 \mathrm{~m}$ or more, the largest share in the electricity consumption for the traction $\mathrm{A}_{\mathrm{T}}$ is attributed 
to that associated with overcoming the track gradient motion resistance. Further, in descending proportion, there follow the consumption for overcoming the forces of resistance to train movement (main, from curves and additional motion), energy loss on excessive gradients and in power circuits, and auxiliary consumption. The relative share of the electricity consumption components for mine trains can be viewed from the data of Table 1 .

Table 1. Components of energy consumption for mine train traction (numerator - in $\mathrm{kWh}$, denominator - in \% of total consumption)

\begin{tabular}{|c|c|c|c|}
\hline \multirow{2}{*}{$\begin{array}{c}\text { Energy } \\
\text { consumption }\end{array}$} & \multicolumn{3}{|c|}{ Travel direction } \\
\hline & Loaded run & Empty run & Per Cycle \\
\hline $\begin{array}{c}\text { Electricity } \\
\text { consumed for }\end{array}$ & 1730 & 190 & 1920 \\
\hline traction $\mathrm{A}_{\mathrm{T}}$ & 100 & $\overline{100}$ & 100 \\
\hline $\begin{array}{l}\text { Electric power } \\
\text { consumption for }\end{array}$ & 113 & 7 & 120 \\
\hline $\begin{array}{c}\text { auxiliary power } \\
\text { supply } \mathrm{A}_{\mathrm{AU}}\end{array}$ & $\overline{6.53}$ & $\overline{1.1}$ & $\overline{6.25}$ \\
\hline $\begin{array}{c}\text { Work of forces to } \\
\text { change the }\end{array}$ & 1076 & -442 & 634 \\
\hline $\begin{array}{c}\text { potential energy } \\
\mathrm{A}_{\mathrm{P}}\end{array}$ & $\overline{62.2}$ & $\overline{-70.0}$ & $\overline{33.02}$ \\
\hline $\begin{array}{l}\text { Work the main } \\
\text { one of the motion }\end{array}$ & 276 & 136 & 412 \\
\hline $\begin{array}{l}\text { resistance forces } \\
\qquad \mathrm{A}_{w_{M}}\end{array}$ & $\overline{15.95}$ & $\overline{21.5}$ & $\overline{21.46}$ \\
\hline \begin{tabular}{lr}
\multicolumn{1}{c}{$\begin{array}{c}\text { Energy } \\
\text { overcome } \\
\text { additional } \\
\text { resistance }\end{array}$} \\
the
\end{tabular} & 32 & 5.5 & 37.5 \\
\hline $\begin{array}{l}\text { the train is } \\
\text { moving with cars } \\
\text { forward } \mathrm{A}_{w_{A}}\end{array}$ & $\overline{1.85}$ & 0.9 & 1.95 \\
\hline $\begin{array}{l}\text { Work of the } \\
\text { motion resistance }\end{array}$ & 60 & 25 & 85 \\
\hline $\begin{array}{c}\text { forces track } \\
\text { gradients } A_{r}\end{array}$ & 3.47 & 4 & 4.43 \\
\hline $\begin{array}{c}\text { Energy } \\
\text { consumption } \\
\text { during } \\
\text { independent }\end{array}$ & 22 & 25 & 47 \\
\hline $\begin{array}{c}\text { braking on } \\
\text { excessive } \\
\text { gradients } \mathrm{A}_{\mathrm{BE}} \\
\end{array}$ & $\overline{1.27}$ & 4 & $\overline{2.45}$ \\
\hline $\begin{array}{l}\text { Energy loss in } \\
\text { braking devices }\end{array}$ & - & 370 & 370 \\
\hline $\begin{array}{c}\text { (excluding } \mathrm{A}_{\mathrm{BE}} \text { ) } \\
\mathrm{A}_{\mathrm{BR}}\end{array}$ & - & $\overline{58.5}$ & $\overline{19.27}$ \\
\hline $\begin{array}{l}\text { Energy losses in } \\
\text { electric traction } \\
\text { circuits of an }\end{array}$ & 151 & 63,5 & 214.5 \\
\hline $\begin{array}{c}\text { locomotive in } \\
\text { traction mode } \\
\Delta \mathrm{A}\end{array}$ & $\overline{8.73}$ & 10 & $\overline{11.17}$ \\
\hline
\end{tabular}

They correspond to the average values determined using the above expressions based on the results of three experimental journeys on a full cycle of traffic on the
$12.35 \mathrm{~km}$ route with the end point height difference of $224.4 \mathrm{~m}$. The experiments were conducted with a PE2 ${ }^{\mathrm{M}}$ traction unit and a train of 9 cars 2VS-105 (train unladen weight $\mathrm{M}=730 \mathrm{t}$; estimated weight of loaded train $\mathrm{m}=$ $1.730 \mathrm{t})$. In Table $1 \mathrm{~A}_{w_{4}}$ - energy to overcome the additional resistance when the train is moving with cars forward.

The energy consumption values averaged by a number of experimental journeys by travel direction in the form of histograms are shown in Fig. 2-4.

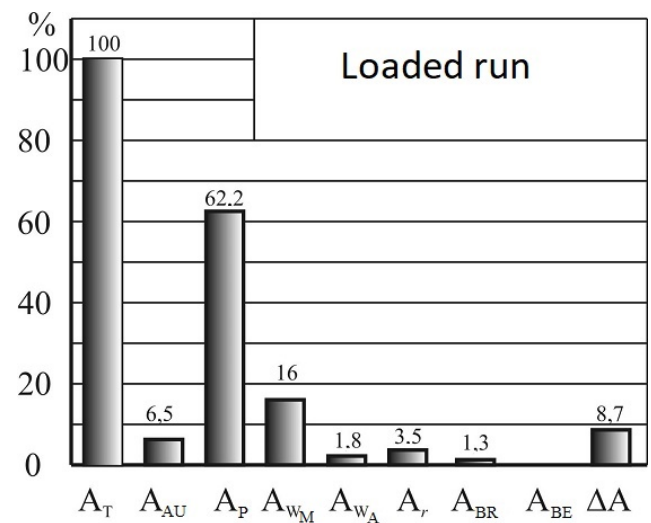

Fig. 2. Distribution of loaded run energy costs by the types of work

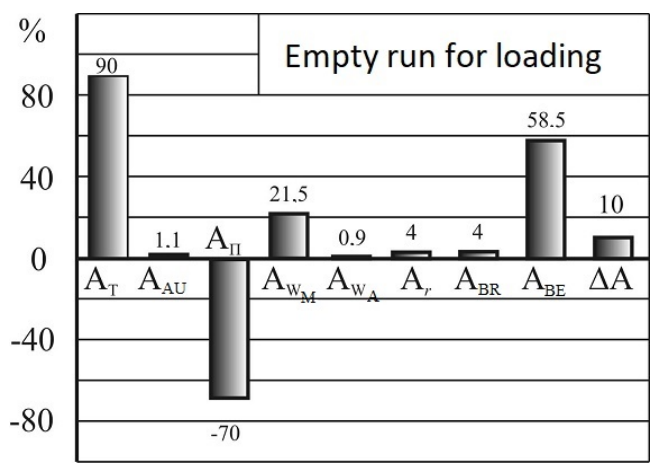

Fig. 3. Distribution of empty run energy costs by the types of work

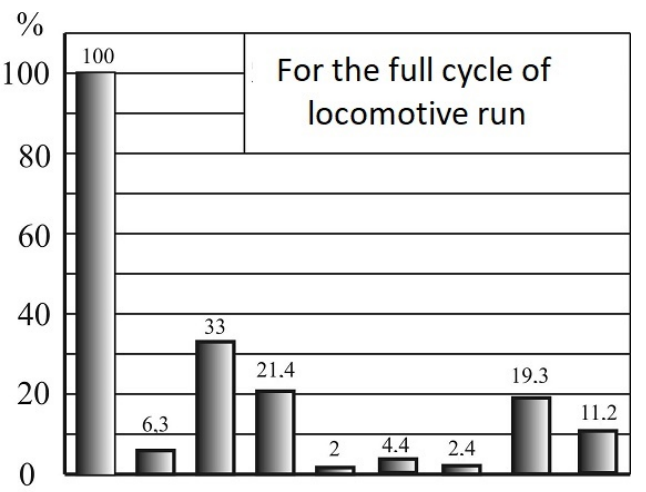

$$
\mathrm{A}_{\mathrm{T}} \quad \mathrm{A}_{\mathrm{AU}} \quad \mathrm{A}_{\mathrm{P}} \mathrm{A}_{\mathrm{W}_{\mathrm{M}}} \mathrm{A}_{\mathrm{W}_{\mathrm{A}}} \mathrm{A}_{r} \quad \mathrm{~A}_{\mathrm{BR}} \quad \mathrm{A}_{\mathrm{BE}} \Delta \mathrm{A}
$$

Fig. 4. Distribution of energy costs by the types of work for the full cycle of the locomotive run

Analysis of the data and calculated expressions shows that the total energy consumption and the proportion of its components depends mainly on the 
characteristics of the route (elevation of the end points; characteristics of the tracks in the places of the train stops and the number of the latter; length of sections with the train moving head forward and cars forward; the number and parameters of the track curves; the share of the length of fixed and movable tracks; track gradient in the places of loading and unloading). In the case under consideration, the largest share in the power consumption falls on the consumption $\mathrm{A}_{\mathrm{P}}$, associated with overcoming the track gradient motion resistance. Further, in descending proportion, there follow the consumption for overcoming the forces of resistance to train movement (main, from curves and additional motion), $-30.84 \%$, energy losses on excessive gradients - $19.27 \%$, in start circuits - $11.17 \%$, and auxiliary consumption $-6.25 \%$.

The main factors determining the structure of electricity consumption in terms of components and energy intensity of transportation should include primarily the rectified gradient of the route. The increase in the height difference at which the loading and unloading points are located, under otherwise equal conditions, leads to higher energy intensity of transportation and growth in the proportion of work for changing the potential energy of a train $A_{P}$.

Reducing the track gradient on the route is accompanied by a decrease in the proportion of the component $\mathrm{A}_{\mathrm{P}}$ and an increase in the share of other components.

The level of the average motion speed has a certain effect. With its reduction, the component $\mathrm{A}_{w_{M}}$ decreases slightly and the auxiliary consumption increases significantly (both in absolute value and in relative share).

For this reason, in some cases (for example, when using traction units $\mathrm{PE} 2^{\mathrm{M}}$ ), the absolute value and relative share of the components $\mathrm{A}_{\mathrm{P}}, \Delta \mathrm{A}$ and $\mathrm{A}_{\mathrm{AU}}$ depends on the level of voltage used in the power supply system of the traction rolling stock.

From the above data, it can be concluded that with current schemes for transporting the mined rock, regardless of the characteristics of the route gradient, the reserves for reducing power consumption for traction should be sought in decreased auxiliary consumption $\mathrm{A}_{\mathrm{AU}}$ and energy losses in electric rolling stock $\Delta \mathrm{A}$, as well as on excessive gradients $\mathrm{A}_{\mathrm{BE}}$.

The structure of the considered energy consumption depends on the characteristics of the route: with an increase in the route length, the share of energy consumption for loaded run increases, and the proportion of the remaining components decreases. With current schemes for transporting the mined rock, regardless of the characteristics of the route gradient, the reserves for reducing power consumption for traction should be sought in decreased power for train movement $A_{T}$ and auxiliary circuit consumption $\mathrm{A}_{\mathrm{AU}}$, reduced energy loss in electric rolling stock $\Delta \mathrm{A}$, while stopping and slowing down on excessive gradients.
The validity of the conclusions made above is confirmed by the results of the analysis of the structure of the operational power consumption and the energy components for auxiliary circuit power supply.

The peculiarity of work of electric transport of the open-cast mining enterprises is its cyclical nature. A typical transportation cycle includes:

- Movement to the open cut;

- Loading (of mineral product or overburden rock);

- Weighing (usually only of trains carrying mineral products);

- Movement with load (to the crushing plant or to dumps);

- Unloading of mined rock.

Electricity consumption for traction per cycle is as follows

$$
\mathrm{A}_{\mathrm{T}}=\mathrm{A}_{\mathrm{ROC}}+\mathrm{A}_{\mathrm{LD}}+\mathrm{A}_{\mathrm{LR}}+\mathrm{A}_{\mathrm{UNL}}+\mathrm{A}_{\mathrm{TW}},
$$

where the components of the right-hand side represent respectively the electricity consumption for:

$A_{R O C}$ - train run to open-cut; $A_{L D}$ - loading of mined rock; $A_{L R}$ - loaded run; $A_{U N L}$ - unloading of mined rock; $\mathrm{A}_{\mathrm{TW}}$ - train weighting.

According to the results of the experimental journeys in the open-cast mines of UGOK and SSGOK by traction units $\mathrm{PE} 2 \mathrm{M}$, we obtained data on the relative share of the above-mentioned electricity consumption by operation.

Their values averaged by a number of experimental journeys in the histogram form are shown in Fig. 5.

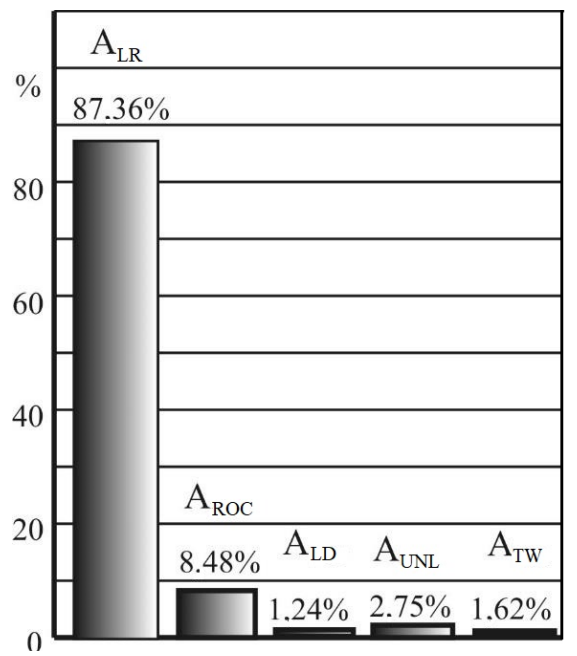

Fig. 5. Electricity consumption by operation for mine trains

It is easy to see that most energy is spent for the loaded run and to open-cut, so when collecting the statistical material necessary for rationing electricity consumption and developing measures to reduce the energy intensity of transportation, particular attention should be paid to choosing rational train control methods during the period of movement, since in this case, even a small percentage reduction in energy consumption can give a significant change in its total consumption.

The design engine power on the ruling gradient corresponds to the conditions of engine overload. The 
overload duration varies widely and depends on the specific gradient of the railway tracks. In the practice of operating electric locomotives, the inertia of the traction motor is always used in order to briefly generate power on the most difficult sections of the track when starting from a standstill. This is possible only if the temperature of the engine at the time of the overload is lower than allowed by the norms. At the end of the power boost period, the temperature and its overheating should not exceed the values allowed for this insulation class.

It was noted above that in the total electricity consumption, a significant share is attributed to the work of auxiliary equipment: compressor engines and fans of traction engines, control devices, lighting, heating, etc.

As applied to the main transport, the issues of saving energy consumption for powering the auxiliary circuits of electric rolling stock were investigated by a number of authors [22-25]. For mine electric transport this issue was not covered in the technical literature known to the authors.

At the same time, the search for savings reserves requires the study of the energy intensity of individual elements of auxiliary circuits, as well as an assessment of the amount of auxiliary energy expenditures during all phases of the transportation cycle. To solve this issue during the experimental journeys the necessary measurements were taken.

At the PE2M traction unit, the total power of auxiliary machines that are powered from the contact network is $390 \mathrm{~kW}$ :

1. Compressor drive engine KCT-6 - two engines of type TL110 (53.1 kW; $20.6 \mathrm{~A} ; 3 \mathrm{kV})$.

2. Engines of type NB101 for driving centrifugal cooling fans of traction motors of electric locomotive and motor dump cars (six electric motors with a capacity of $41 \mathrm{~kW}$ each; $36 \mathrm{~A} ; 1.5 \mathrm{kV}$ ) or DT-51 engines, with parameters and design identical to those of NB-101.

3. DK-604V type dynamotor-generator for supplying control circuits with $50 \mathrm{~V}$ voltage and recharging the battery $(2 \times 6 \mathrm{~kW} ; 5.3 \mathrm{~A} ; 2 \times 1.5 \mathrm{kV})$.

4. Electric motors of type ETV-20 for driving axial cooling fans of the brake-start resistors (six motors with a power of $13 \mathrm{~kW}$ each; $200 \mathrm{~V} ; 80 \mathrm{~A}$ ).

Based on the foregoing, the auxiliary power consumption can be represented as

$$
\mathrm{A}_{\mathrm{AU}}=\mathrm{A}_{\mathrm{FE}}+\mathrm{A}_{\mathrm{CE}}+\mathrm{A}_{\mathrm{GE}}+\mathrm{A}_{\mathrm{CH}} \text {, }
$$

where the components of the right-hand side represent the electricity consumption for the power supply of the respective circuits: $\mathrm{A}_{\mathrm{FE}}$ - fan engines; $\mathrm{A}_{\mathrm{CE}}-$ compressor engines; $\mathrm{A}_{\mathrm{GE}}$ - generator engines; $\mathrm{A}_{\mathrm{CH}}-$ driver's cab heating.

The values of the components of auxiliary energy consumption, obtained experimentally, are given in the form of diagrams in Fig. 6...10, where the energy consumption is indicated respectively: FE - fan engines, $\mathrm{CE}$ - compressor engines, GE - motor-generators, $\mathrm{CH}$ for driver's cab heating. It can be seen that during the loading (fig. 6) and unloading (fig. 7) period, the main part of the power consumption $\mathrm{A}_{\mathrm{AU}}$ is due to the operation of the compressor engines (62-85\%).

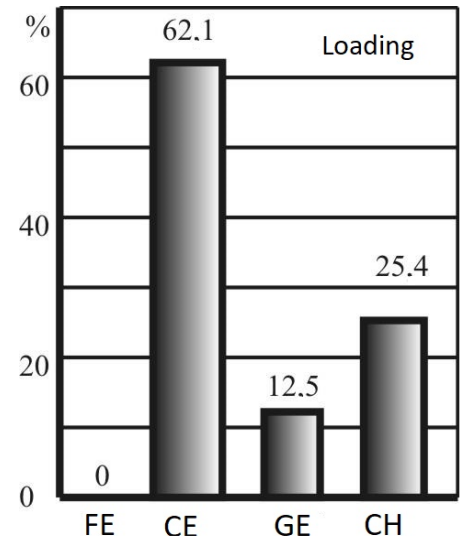

Fig. 6. Auxiliary electricity consumption during loading

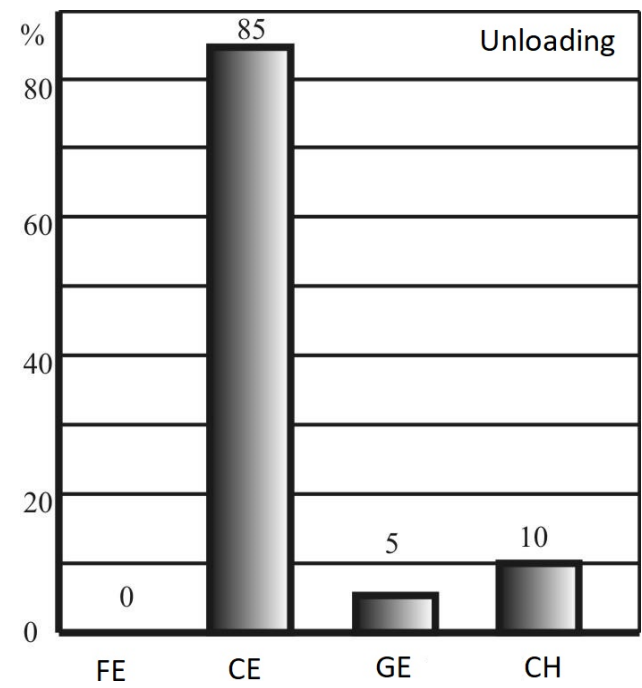

Fig. 7. Auxiliary electricity consumption during unloading

When running with a load (Fig. 8), the auxiliary consumption is mainly due to the operation of the fan engines of the traction motors $(83.6 \%)$.

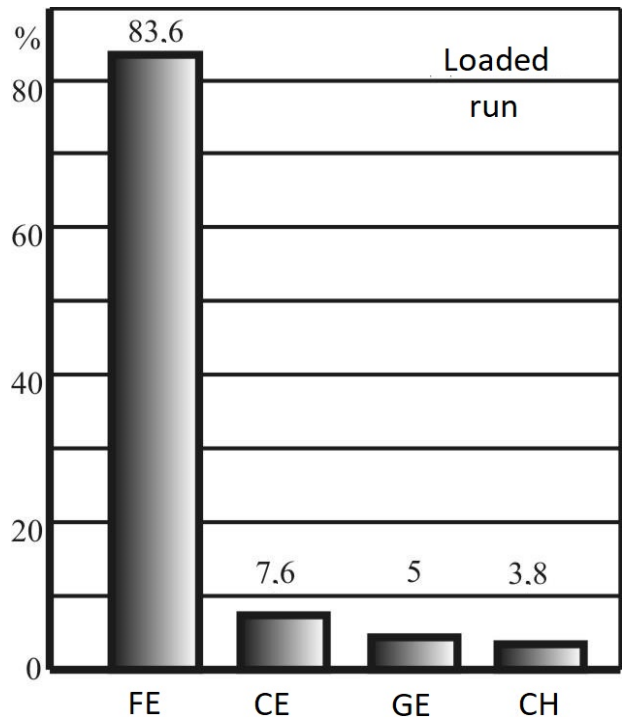

Fig. 8. Auxiliary electricity consumption during loaded run 
When running to open-cut (Fig. 9), 28.5\% of $A_{A U}$ are due to the operation of the generator engines of control circuit, while the share of the compressor engines accounts for $44.3 \%$ of the energy consumption.

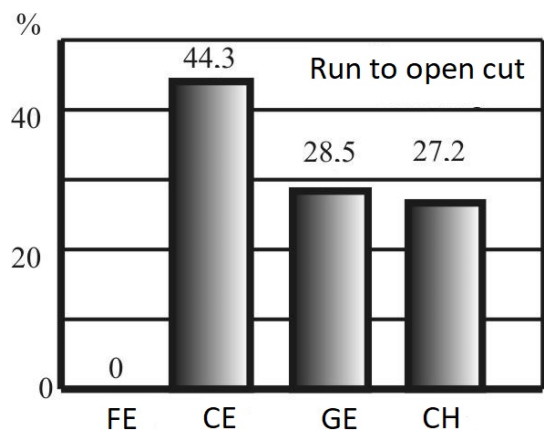

Fig. 9. Auxiliary electricity consumption during run to opencut

For the full cycle of running (Fig. 10), more than half of the auxiliary energy consumption is due to the ventilation of the traction motors $(59.3 \%)$. The operation of compressor engines takes $25.4 \%$ of $\mathrm{A}_{\mathrm{AU}}$, the power of the generator engine $-7.4 \%$. The heating of the driver's cab in winter is $7.9 \%$ of $\mathrm{A}_{\mathrm{AU}}$.

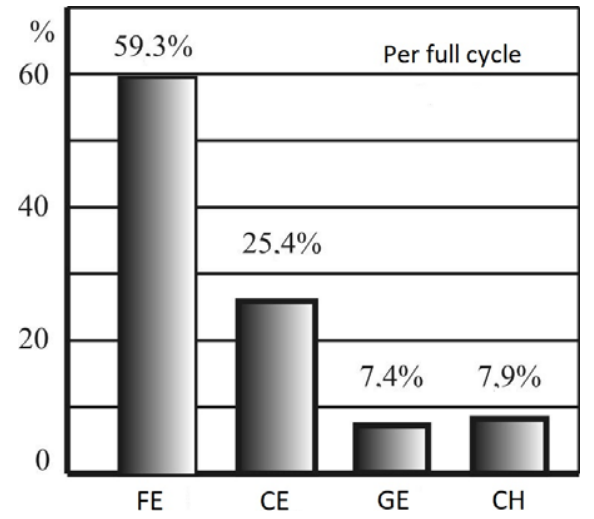

Fig. 10. Auxiliary electricity consumption structure per cycle

The above data correspond to the usual mode of operation of auxiliary machines in mine transport, which involves the switching on of traction motor fans only for the loaded run period. Consequently, in the case of longer operation of the fans, the share of auxiliary consumption in the total energy consumption will increase. It also follows from the above that if there is a reserve for heating the windings of the traction motors for specific operating conditions, then in this case it is possible to reduce the auxiliary power consumption by using the reduced fan performance mode.

\section{Conclusions}

1. The performed study of the electricity consumption structure is the basis for the development of technical and operational measures to reduce the energy intensity of the mine transportation process.

2. Work to reduce the electricity consumption for mine transportation should be aimed at:

- Reduction of losses in the power circuits of the traction rolling stock due to the use of more advanced electric rolling stock and regulation of the degree of utilization of the installed traction power;

- Introduction of measures to reduce energy consumption for power supply of auxiliary circuits;

- Development and implementation of rational train control techniques.

3. The introduction of energy-saving measures should include the development and application of effective methods for calculating individual norms of energy consumption and incentives for energy saving of the employees involved in the organization of the transportation process (first of all, train crews);

4. It is advisable to perform a comparative analysis of the energy consumption of the transportation process depending on the type of current and voltage level in the traction power supply system.

5. The results of the analysis of the components of electrical energy consumption for mine train traction given in this article can be used in the development of measures to reduce the energy intensity of transportation at open-cast mining enterprises.

\section{References}

1. S. M. Boyko Electrification of Transport. On the development of the power supply system of mining enterprises using renewable sources of electricity. 14, 7-14 (2017) [in Russian]

2. S. P. Denisyuk Electrification of Transport. Increasing the energy efficiency of rail transport enterprises based on the technological approach. 14. 78-85 (2017) [in Russian].

3. V. G. Sychenko Quality of electric energy in traction networks of electrified railways. (2015) [in Ukrainian]

4. O. N. Sinchuk Electric Transport. Small commentary on the tactics of creating traction electromechanical complexes of combined mine electric locomotives. 14, 42-55 (2017) [in Russian]

5. I. B. Malyshko Bulletin of Dnipro Nat. Un-ty of Railway Transport n. a. Acad. V. Lazaryan. Main directions of energy saving on the railway transport of Ukraine. 13. 36-38 (2006). [in Ukrainian]

6. O. I. Sablin, D. O. Bosyi, V. G. Kuznetsov, M. O. Babyak, Ye. M. Kosarev, P. V. Gubsky. Visnyk of Vinnytsia Polytechnical Institute. Efficiency of electric energy recuperation in the electric transport system with inverter DC traction stations. 2, 72-78. (2016) [in Ukrainian]

7. M. O. Babyak. Visnik of the East Ukr. Nat. Un-ty. Resource-saving technology for the use of current collector plates, taking into account their interaction with the contact wire. 2. 32-37 (2018) [in Ukrainian]

8. Babyak M, Horobets V, Sychenko V, Horobets Y. Eastern-European Journal of Enterprise Technologies. Comparative tests of contact elements at current collectors in order to comprehensively 
assess their operational performance 12, 13-21 (2018).

9. M. O. Babyak, V. L. Horobets, V. V. Artemchuk. Electrical Contacts and Electrodes. Study of physical mechanical properties of pantograph plates used as current-moving elements of electric rolling stock. K.: IPM NAS of Ukraine. 89-100 (2016). [in Ukrainian]

10. Kalivoda, J., \& Neduzha, L. Simulation of Safety Against Derailment Tests of an Electric Locomotive. Proc. of 25th Intern. Conf. "Engineering Mechanics 2019”, 177-180 (2019). doi: 10.21495/71-0-177

11. Kyryl'chuk, O., Kalivoda, J., Neduzha, L. High Speed Stability of a Railway Vehicle Equipped with Independently Rotating Wheels. Proc. of 24th Intern. Conf. "Engineering Mechanics 2018", 473-476. (2018). doi: 10.21495/91-8-473.

12. Shydlovskui R. M., Babyak M. O., Artemchuk V. V. Visnik of the East Ukr. Nat. Un-ty. Analysis of the possibilities of increasing the operational characteristics of the mechanical part of electric locomotives. 1, 240-244 (2016). [in Ukrainian]

13. Shydlovskui R. M., Babyak M. O., Artemchuk V. V. Electrification of Transport. Modern state of reliability of the elements of the mechanical part of freight electric locomotives. 12, 92-97 (2016) [in Ukrainian]

14. L. Bondarenko, M. Babyak, S. Yakovlev, S. Istin, G. Moskalev. Science and Transport Progress. Relationship Between Rolling and Slip Resistance in Rolling Bearings. 3. 161-170 (2016) - doi: $10.15802 /$ stp2016/74760

15. S. V. Myamlin, V. L. Horobets, O. L. Yangulova, M. O. Babyak. Bulletin of Certification of Railway Transport. About rational organization of the rolling stock repair system. 10, 58-60 (2016) [in Russian]

16. V. I. Mozgovoi. The World of Technics and Technology. Electricity - consumption and accounting. Modern methods: Rational use and accounting of energy resources. Application of automated electric energy accounting system. 11, 56-58 (2005) [in Russian]

17. M. P. Silich. Industrial power engineering. Energy Saving: Assessment of energy saving level in the region. Saving energy resources. 3, 2-6 (2006) [in Russian]

18. V. S Dziuban. Energy Saving. Energy resource saving is a priority task of Ukrainian enterprises. Reduction of energy consumption by mining enterprises. 11, 10-11 (2006) [in Russian]

19. Yu. I. Lel Innovative transport. Power engineering of mine transport. 1. 34-39 (2011) [in Russian]

20. S. M. Bro, A. S. Prygunov, S. A. Shypunov. Coll. of Res. Papers of the Nat. Mining Un-ty. Comparative analysis of energy consumption by various types of mine transport. 38. 84-89 (2012). [in Russian]

21. Yu. I. Anistratov. Method of determining the energy efficiency of technologies and mechanization of open-pit mining operations (2011). [in Russian]

22. H. K. Hetman, V. E. Vasiliev. Bulletin of Dnipro Nat. Un-ty of Railway Transport n. a. Acad. V. Lazaryan. Analysis of electric power consumption for mine train traction. 36. 70-74 (2011) [in Russian]

23. V. G. Kuznetsov, M. O. Ivanov, O. O. Matusevich. Bulletin of Dnipro Nat. Un-ty of Railway Transport n. a. Acad. V. Lazaryan. Rationing of auxiliary electric power consumption for sectionalizing and parallel dc connection points. 25. 30-33 (2008) [in Ukrainian]

24. V. A. Gapanovich. Energy saving on rail transport. (2012). [in Russian]

25. H. K. Hetman, V. E. Vasilyev. Electrification of Transport. Once more about determination of the power consumption for traction by means of partial disconnection of traction motors of the electric rolling stock 5, 33-40 (2013) [in Russian] 